\title{
PENGARUH DESAIN INTERIOR PERPUSTAKAAN TERHADAP KENYAMANAN PENGGUNA DI PERPUSTAKAAN UNIVERSITAS POTENSI UTAMA
}

\author{
Sri Wahyuni Panjaitan \\ Prodi Desain Interior \\ Fakultas Seni dan Desain Universitas Potensi Utama Medan \\ yuniwandriani@gmail.com
}

\begin{abstract}
ABSTRAK
Tujuan dari tulisan ini adalah untuk mengetahui pengaruh desain interior perpustakaan terhadap kenyamanan pengguna di perpustakaan Universitas Potensi Utama dan untuk mengetahui elemenelemen desain interior yang berpengaruh pada kenyamanaan pengguna. Perpustakaan sebuah perguruan tinggi merupakan sebuah wadah untuk menemukan ilmu pengetahuan dan sumber informasi lainnya. Perpustakaan pada sebuah perguruan tinggi merupakan tempat yang penting untuk dipenuhi sehingga dapat mendukung proses belajar mahasiswa, disana mereka dapat menemukan ilmu pengetahuan dan sumber informasi lainnya. Hal yang harus diperhatikan agar pengunjung betah berlama-lama di perpustakaan adalah elemn-elemen desain interior sehingga dapat menciptakan kenyamanan di perpustakaan, karena desain interior merupakan hal yang penting untuk merancang suatu bangunan seperti perpustakaan. Rancangan bangunan perpustakaan perlu diperhatikan setiap fungsi ruangannya, kenyamana, keharmonisan dan keindahan ruangan dari segi interior. Ruang perpustakaan akan terlihat nyaman bagi pengunjung ketika ruang tersebut ditata dengan memperhatikan tata letak, warna, suhu udara, dan pencahayaan. Kenyamanan pengunjung ataupun pengguna perpustakaan dapat dilihat dari elemen desain interior seperti tata letak, warna,suhu udara, pencahayaan yang diterapkan. Hasil dari penelitian ini menyimpulkan bahwa desain interior perpustakaan Universitas Potensi Utama dapat dikatakan baik seperti suhu udara, pewarnaan, pencahayaan, namun tata letak meja dan kursi tidak memberikan kenyamanan.
\end{abstract}

Kata kunci : kenyamanan pengguna, desain interior

\begin{abstract}
The purpose of this paper is to find out the effect of library interior design on the convenience of users in the library of the University of Main Potential and to find out elements of interior design that influence user comfort. The library of a college is a place to find knowledge and other sources of information. The library at a college is an important place to be fulfilled so that it can support the learning process of students, there they can find knowledge and other sources of information. Things that must be considered so that visitors feel at home lingering in the library are elements of interior design so that they can create comfort in the library, because interior design is important to design a building such as a library. The design of the library building needs to be considered every function of the room, comfort, harmony and beauty of the room in terms of interior. The library space will look comfortable for visitors when the space is arranged by paying attention to the layout, color, air temperature, and lighting. The convenience of visitors or library users can be seen from interior design elements such as layout, color, air temperature, lighting applied. The results of this study concluded that the interior design of the University's Main Potential can be said to be good such as air temperature, coloring, lighting, but the layout of tables and chairs does not provide comfort.
\end{abstract}

Keywords: user comfort, interior design 


\section{PENDAHULUAN}

Pada era globalisasi seperti sekarang ini, pendidikan merupakan suatu yang sangat penting, karena pendidikan merupakan akar dari peradaban sebuah bangsa. Pendidikan sekarang telah menjadi kebutuhan pokok yang harus dimiliki setiap orang agar bisa menjawab tantangan kehidupan. Dalam memperlancar pendidikan, banyak cara yang dapat kita lakukan, salah satunya memperbanyak membaca melalui perpustakaan. Perpustakaan merupakan suatu lembaga yang bertugas untuk mengumpulkan, mengola, menyimpan, menyebarluaskan dan melestarikan informasi. Sama halnya dengan perpustakaan umum yang merupakan suatu perpustakaan yang didirikan oleh pemerintah setempat untuk kepentingan umum atau masyarakat dengan tujuan masyarakat biasa memanfaatkan segala fasilitas yang ada, dan berhak mendapatkan informasi yang baik, benar sesuai dengan kebutuhan masing-masing pemustaka tanpa memandang status sosial.

Perpustakaan adalah ruang yang terdapat berbagai sumber ilmu pengetahuan dan informasi. Sumber-sumber ilmu pengetahuan dan informasi yang ada dalam perpustakaan tidak hanya dihimpun, diolah dan disimpan saja, namun juga disebar luaskan kepada pengguna perpustakaan. Perpustakaan adalah tempat untuk menyimpan dan menemukan kembali ilmu pengetahuan dan informasi. Ilmu pengetahuan dan informasi yang terdapat dalam koleksi perpustakaan adalah sumber kekuatan dari berbagai bidang ilmu. Perpustakaan sebagai salah satu lembaga yang berfungsi sebagai wadah dalam pengelolaan informasi dihadapkan pada tuntutan perkembangan. Salah satu aktivitas yang dilakukan di perpustakaan adalah untuk memenuhi kebutuhan informasi seperti membaca. Selain itu perpustakaan tidak hanya sekedar gedung yang berisikan buku dan informasi untuk dibaca, namun juga berfungsi sebagai tempat mencari kesenangan, belajar, juga melakukan penelitian kecil, berdiskusi, hingga menggunakan internet yang telah disediakan oleh perpustakaan untuk meng-update informasi.

Faktor terpenting yang dapat menunjang keberhasilan sebuah perpustakaan adalah perpustakaan berusaha membuat berbagai macam peningkatan agar pemustaka merasa nyaman berada dalam perpustakaan. Hal ini perlu adanya perubahan sarana penunjang yang dapat membuat permustaka nyaman berada diperpustakaan. Sarana penunjang tersebut dapat ditonjolkan pada desain interior perpustakaan.

Perancangan bangunan pada perpustakaan perguruan tinggi, desain interior perpustakaan merupakan peran penting dalam memperbaiki fungsi, memperkaya nilai estetika yang dapat meningkatkan aspek psikologis dari ruang interior perpustakaan. Nilai estetika menjelaskan bagaimana sebuah ruang perpustakaan bisa terlihat indah dan dapat memberikan kesan nyaman bagi pengunjung yang berada di dalam. Tiap desain memiliki tujuan untuk menyusun secara teratur pada bagian satu dengan bagian lainnya menjadi suatu tatanan yang utuh untuk maksud-maksud tertentu. Menurut Kugler desain interior terdiri dari elemen-elemen di dalamnya yaitu ruang, variasi, hirarki, area personal, pencahayaan, tata suara, suhu udara, perawatan, kualitas udara, serta gaya dan fashion.

Wiji Suwarno mengatakan bahwa ruang perpustakaan tidak hanya sekedar sekat yang memisahan ruang satu dengan ruang lainnya. Penataan ruang perpustakaan perlu dilakukan secara hati-hati dengan mempertimbangkan berbagai aspeknya. Perpustakaan merupakan kegiatan yang berorientasi pada pelayanan dalam bentuk jasa dan orang yang datang untuk memanfaatkannya. Untuk dapat membuat pengunjung merasa nyaman berada dalam perpustakaan maka salah satu cara yang dapat dilakukan adalah melalui penataan ruangan yang menarik dan fungsional (Suwarno, 2009:99). 
Menurut (Daryanto, 1986: 28) gedung perpustakaan yang baik ditandai dengan beberapa sifat yang membuatnya efesien, memudahkan pemakai dan memberi lingkungan yang nyaman, menyenangkan dan menarik sebagai tempat mencari dan belajar.

Desain interior adalah salah satu hal yang cukup penting dalam rancangan suatu bangunan, khususnya dalam hal ini adalah pembangunan perpustakaan. Perpustakaan yang baik dalam perencanaan gedung dan ruang perpustakaan perlu memperhatikan fungsi tiap ruang, unsur-unsur keharmonisan dan keindahan. Hal tersebut dimaksudkan agar dapat memberikan kenyamanan kepada pemustaka khususnya dalam hal ini perpustakaan umum yang tidak lain penggunanya adalah mahasiswa dan masyarakat sekitar.

Menurut Lasa, (dalam Adrina 2013, hlm. 2) "desain interior sangat penting untuk diperhatikan, karena kaitannya adalah dengan kenyamanan pengguna, jika pemustaka merasa nyaman berada di perpustakaan, maka pemustaka akan senang untuk datang kembali ke perpustakaan". Penelitian ini akan menganalisis elemen-elemen yang terkait pada desain interior perpustakaan yaitu pencahayaan, tata letak, suhu udara, dan warna.

\section{STUDI LITERATUR}

\section{II.1. Pengertian Desain Interior}

Menurut Nurhayati dalam Rahmat Arsyad (2014:13) desain berasal dari kata bahasa inggris design dalam bahasa indonesia sering digunakan padanan katanya, yaitu rancangan, pola atau cipta. Desain merupakan suatu proses pengorganisasian unsur garis, bentuk ukuran, warna, tekstur, bunyi, cahaya aroma, dan unsur desain lainnya, sehingga tercipta suatu hasil karya tertentu.

Desain interior adalah hubungan untuk menciptakan suasana yang kondusif dan nyaman penataan ruangan agar efektif dan efisien pada tata letak, ventilasi, cahaya, warna, serta suara (kebisingan) dan tempat strategisnya. Desain berasal dari kata bahasa inggris design, dalam bahasa Indonesia sering digunakan padana katanya, yaitu rancangan, pola atau cipta. Desain merupakan suatu proses perorganisasian unsur garis, bentuk ukuran, warna, tekstur, bunyi, cahaya, aroma, dan unsur-unsur desain lainnya, sehingga tercipta suatu hasil karya tertentu (Nurhayati, 2004:9).

Berdasarkan Kamus Besar Bahasa Indonesia (2008:348) kata desain dan interior memiliki arti motif atau corak ruang dalam gedung. Desain interior merupakan kegiatan merencanakan, menata dan merancang ruang alam bangunan. Penataan suatu ruang bertujuan agar pengguna merasa nyaman, betah dan senang berada di ruangan tersebut. Menurut Cohen (1994:547) terdapat beberapa faktor yang mempengaruhi desain interior suatu gedung yaitu ruang, warna, pencahayaan, sirkulasi udara dan tata suara.

Menurut (Kamus Besar Bahasa Indonesia, 2008:346), desain adalah gagasan awal, rancangan, perancanaan pola susunan, kerangka bentuk suatu bangunan, motif bangunan, pola bangunan, corak bangunan.

Dalam (Kamus Besar Bahasa Indonesia, 2008:560), interior adalah bagian dalam gedung atau ruang, tatanan prabot atau hiasan di dalam ruang bagian dalam gedung. Bila diartikan, desain interior adalah gagasan awal yang diperuntukkan bagi suatu ruangan atau suatu perencanaan dari bagian dalam suatu bangunan sehingga ruangan tersebut memiliki nilai kehidupan (estetika).

Menurut (Suptandar,1995:11) desain interior berarti suatu sistem atau cara pengaturan ruang dalam yang mampu memenuhi persyaratan kenyamanan, keamanan, kepuasan kebutuhan fisik dan spiritual bagi penggunannya tanpa mengabaikan faktor estetika. 
Dari beberapa pengertian desain dan desain interior diatas dapat disimpulkan bahwa desain interior perpustakaan adalah suatu sistem penataan ruang dalam yang berfungsi sebagai tempat bernaung dari kondisi lingkungan dengan ciptaan suasan dan citra ruang yang memenuhi persyaratan kenyamanan, keamanan, kepuasan kebutuhan fisik dan spiritual penggunannya tanpa mengabaikan faktor estetika.

Elemen - elemen desain interior Kugler (2007), mengatakan bahwa terdapat beberapa unsur pembentuk desain interior diantaranya adalah area personal, suhu udara, kualitas udara, variasi, ruang, pencahayaan, perawatan, hirarki, gaya, tata suara dan fashion.

1. Ruang (Tata Letak)

Pada perpustakaan yang akan dirancang dengan baik harus bisa beroperasi tanpa bergantung dengan ketersediaan penunjuk arah (signage). Elemen interior harus jelas terutama jika ruang tersebut mempunyai ukuran yang besar atau kompleks. Dinding, lantai, serta furnitur, penempatan dan ukuran berbagai hal wajib menekankan atau membedakan antara fungsi dan kegiatan yang berbeda dalam total ruang.

2. Variasi (Keberagaman Jenis Ruang)

Sebagai makhluk sosial yang ditandai dengan peningkatan pada berbagai keinginan, maka perpustakaan yang baru wajib menyiapkan berbagai bentuk preferensi pengguna perpustakaan. Minimal perpustakaan bisa menyiapkan berbagai macam ruang berdasarkan kesesuaian pada tiap karakteristik keperluan pengguna, baik individual ataupun kelompok, seperti ruang untuk membaca individual serta berkelompok. Berbagai jenis model posisi tempat duduk yang bermacam - macam yang disediakan untuk pemenuhan kebutuhan belajar dan kenyamanan pengguna wajib mempertimbangkannya sebagai tujuan dalam memenuhi keinginan pengguna.

3. Hirarki

Penciptaan hirarki visual bisa membantu dalam pemisahan pada berbagai jenis tingkatan informasi maupun dapat membantu batas - batas agar dapat membedakan tiap-tiap ruang yang ada pada perpustakaan. Dinding, lantai, furnitur, ukuran, dan penempatan ruang wajib bisa memberikan tekanan atau perbedaan pada setiap fungsi dan kegiatan yang ada pada keseluruhan ruang dan perbedaan tingkatan yang mereka tonjolkan.

4. Area Personal

Para ilmuwan mengatakan bahwa manusia mempunyai keperluan sosiologis dan psikologis agar dapat menciptakan sebuah tempat dan suasana yang diinginkan. Untuk menyediakan area personal dalam hal ini yaitu menggunakan tempat secara individual pada area yang bisa digunakan secara kelompok, perpustakaan wajib mempunyai arti yang jelas untuk hal tersebut, sehingga pengguna merasa nyaman, aman, dan dihargai

5. Pencahayaan

Pencahayaan dalam perpustakaan umumnya memiliki kecenderungan yang lebih terang dan biasa seragam jenisnya secara keseluruhan. Di perpustakaan modern juga menginginkan bahwa beberapa tingkat cahaya bisa membantu pengguna untuk menentukan kegiatan serta kualitas mereka ketika berada didalam perpustakaan, serta penerangan jumlah lampu juga bisa memberikan dampak positif yang cukup besar terhadap keamanan dan kenyamanan visual pengguna perpustakaan.

\section{Kenyamanan}

Kenyamanan adalah adanya rasa nyaman dan aman berdasaarkan dengan kondisi maupun pada lingkungan sekitar ketika seseorang berada disuatu tempat. Perencanaan gedung yang baik dapat memperoleh tempat kerja yang lebih efisien, menyenangkan, nyaman bagi staf/pegawai perpustakaan ataupun para pengunjung (Sulistyo, 1991: 303) Kenyamanan akan semakin terasa baik dapat mengindikasikan adanya motivasi tinggi untuk 
berkunjungn ke perpustakaan. Ruang yang nyaman dapat menyebabkan pengguna merasa tidak tertekan, gelisah, dan merasa mendapatkan kebebasan beraktifitas diruangan (Sukesi dalam Adianto, Alfian, 2011 ). Berdasarkan pada pendapat-pendapat diatas, dapat menyimpulkan bahwa kenyamanan adalah hal yang sangat penting untuk diperhatikan oleh tiap individual, karena dengan adanya rasa nyaman terhadap lingkungan di sekitarnya ketika berada di suatu tempat, maka secara tidak langsung dapat memberikan dampak positif yang positif bagi individual tersebut.

\section{PEMBAHASAN}

1. Perpustakaan Universitas Potensi Utama

Universitas Potensi Utama merupakan salah satu Universitas Swasta yang ada di Sumatera Utara tepatnya di Kota Medan. Universitas ini berdiri sejak tahun 2014. Sebelumnya Yayasan Potensi Utama merupakan Sekolah Tinggi Manajemen Informatika dan Komputer yang berdiri pada tahun 2003. Universitas Potensi Utama memiliki sebuah perpustakaan untuk mendukung proses belajar mengajar.

2. Fasilitas Perpustakaan Universitas Potensi Utama

Universitas Potensi Utama memiliki beberapa fasilitas koleksi buku yaitu sebagai berikut :

- kursi

- meja

- rak buku

- koleksi buku

- koleksi jurnal

- koleksi majalah

- koleksi prosiding

- buku-buku mata kuliah

- laporan PKL

- laporan Skripsi

- Koran

Selain koleksi buku-buku pengetahuan, perpustakaan juga memiliki fasilitas untuk memberikan kenyamanan bagi para pengunjung perpustakaan, maupun staff perpustakaan yaitu sebagai berikut :

- $\mathrm{AC}$

- CCTV

- Stop Kontak

\section{Layout ( Tata Letak)}

Tata letak ruang merupakan tatanan dan pengaturan yang dibuat seefisien mungkin tata letak semua perlengkapan dan perabotan perpustakaan pada ruang serta lantai kerja yang telah tersedia demi dapat menjamin adanya tempat yang memilki keleluasaan kerja sebaik-baiknya bagi para setiap staf/pegawai. Masalah efisiensi dalam memanfaatkan ruang serta lantai tempat kerja tersebut tidak bisa dipisahkan dari tata letak susunan ruang ataupun unit kerja lainnya dari seluruh bagian.

Sasaran terakhir dari tata letak ruang perpustakaan secara menyeluruh adalah agar dapat memperlancar komunikasi, mempermudah koordinasi serta pengawasan, dan dengan 
demikian dapat meningkatkan efisiensi kerja pada umumnya. Ketika adanya perubahan yang dapat mengakibatkan pengaruh terhadap perpustakaan maka perlu dilakukan peninjauan tata letak ruang perpustakaan. Layout yang terdapat di perpustakaan Universitas Potensi Utama akan dijelaskan sebagai berikut :

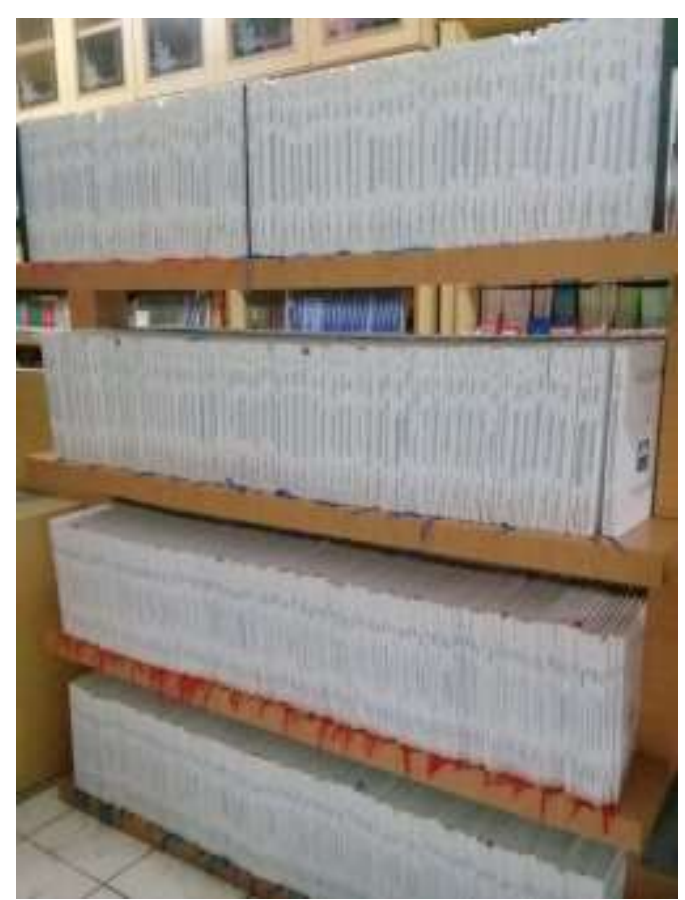

Gambar 1: Koleksi PKL dan Skripsi

Rak koleksi laporan PKL dan skripsi diletak ditengah ruangan agar mudah untuk diakses oleh pengunjung pustaka maupun staf/pegawai pustaka. Koleksi laporan PKL dan Skripsi disusun dengan posisi berdiri, agar mudah dicari dan dibaca oleh pengunjung. Dengan tata letak laporan tersebut memberikan kenyamana bagi para pengunjung perpustakaan.

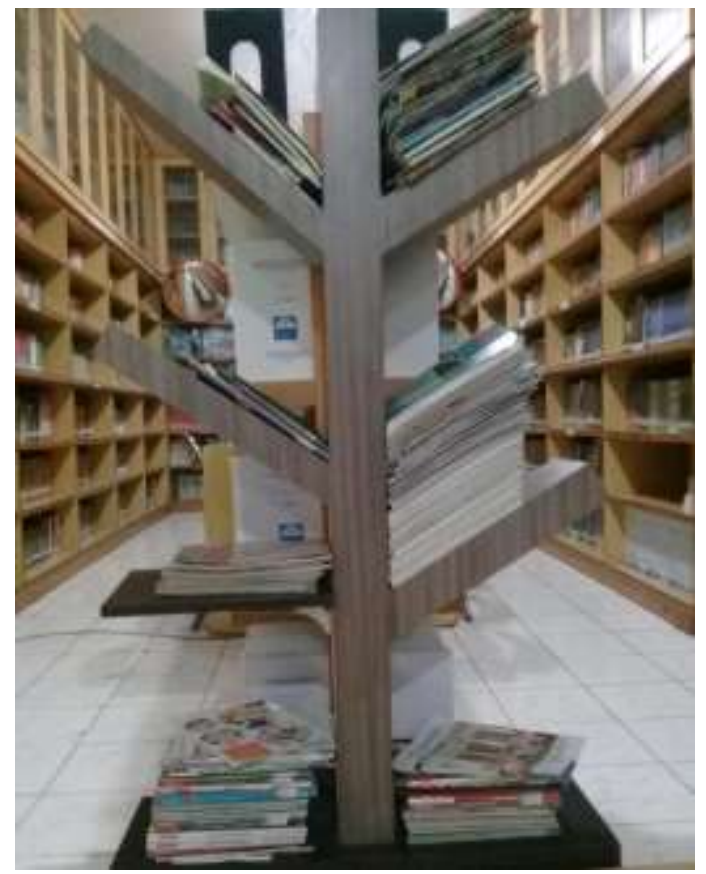

Gambar 2: Koleksi Majalah 
Rak koleksi majalah ini di letak ditengah perpustakaan disamping rak koleksi laporan PKL dan Skripsi. Tata letak koleksi majalah sangat strategis karena letaknya yang mudah dijangkau dan tidak mengganggu aalur lalu lintas di perpustakaan.

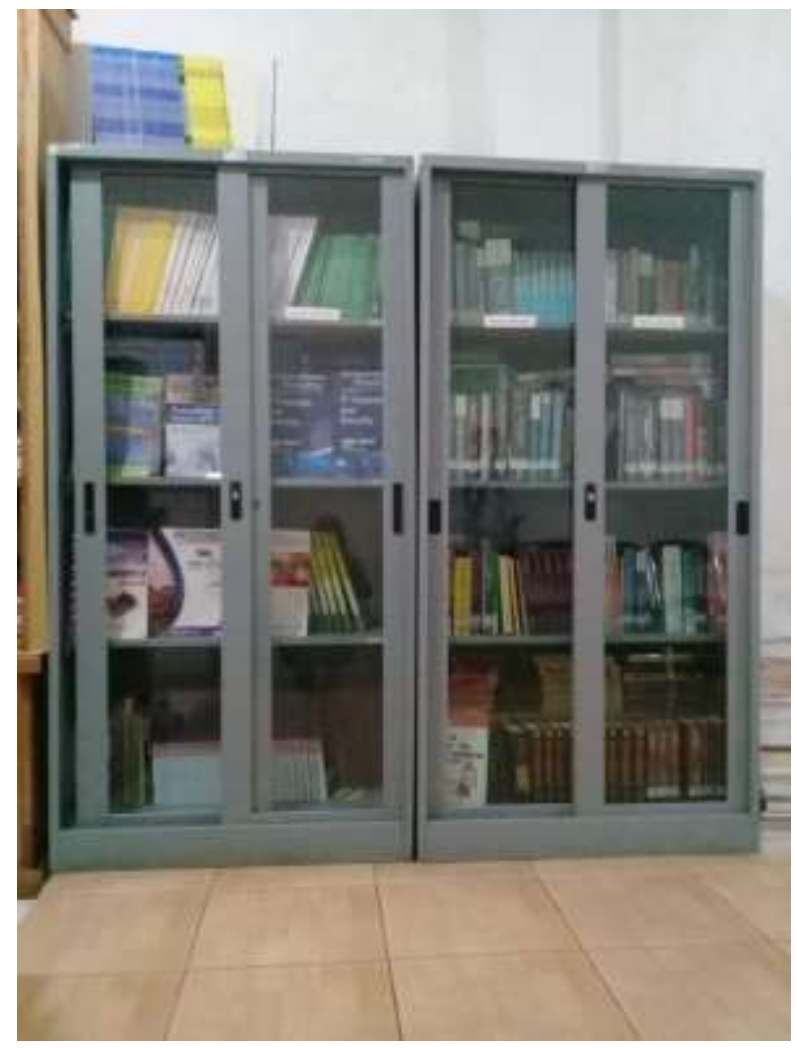

Gambar 3: Koleksi Prosiding

Koleksi prosiding disusun dengan posisi berdiri di dalam lemari kaca agar mudah untuk dibaca. Koleksi prosiding ini disusun berdasarkan tahunnya. Letak lemari prosiding di sandarkan ke dinding agar tidak menghalagi lalu lintas perpustakaan, sehingga pengunjung merasa nyaman untuk berlalu lintas di dalam perpustakaan.

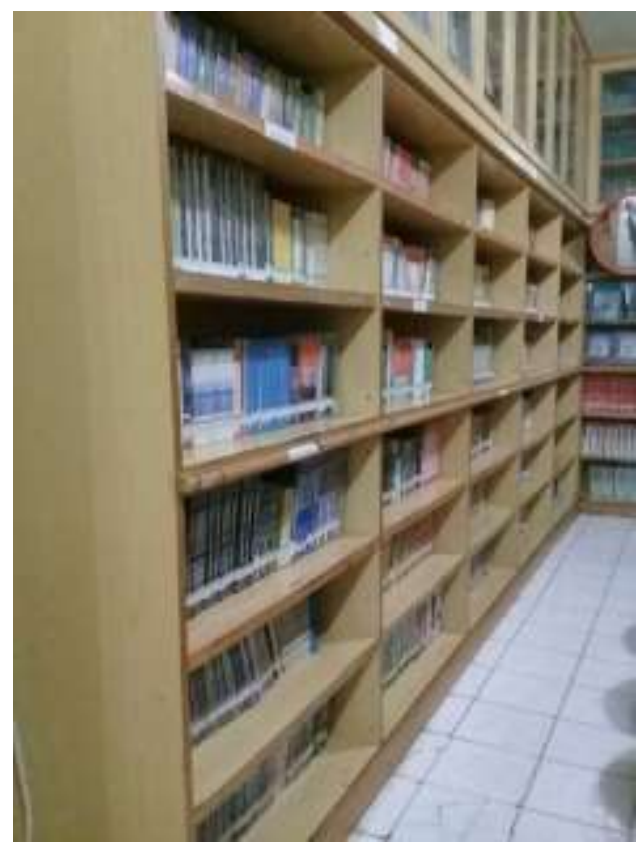

Gambar 4: Koleksi Buku 
Koleksi buku disusun dengan posisi berdiri agar mempermudah untuk mencari dan mengambilnya. Koleksi buku ini diberi sekat, sehingga tidak berantakan ketika diambil oleh pengunjung. Jarak antar sekat ini berskisar sekitar $60 \mathrm{~cm}$, setiap sekat rak buku ini terdapat buku-buku dengan bidang ilmu yang sejenis.

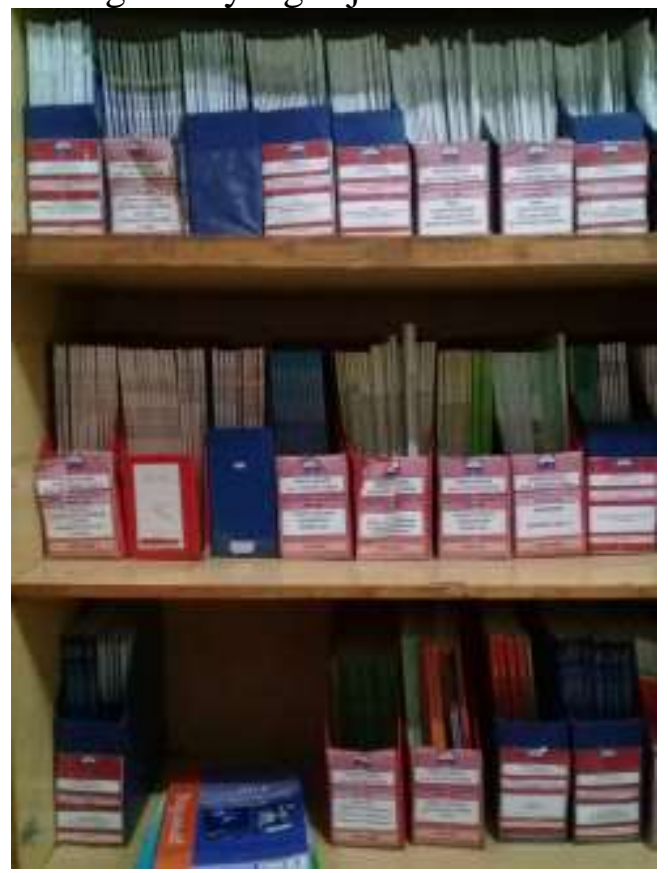

Gambar 5: Koleksi Jurnal

Koleksi jurnal disusun didalam box file berdasarkan dengan bidang ilmu dan diberi dengan label. Box file jurnal tersebut diletakkan di rak buku dan disekat agar tidak bergabung dengan buku berguna untuk mempermudah dalam proses pencarian. Jurnal ini disusun di dalam box file dengan posisi berdiri.

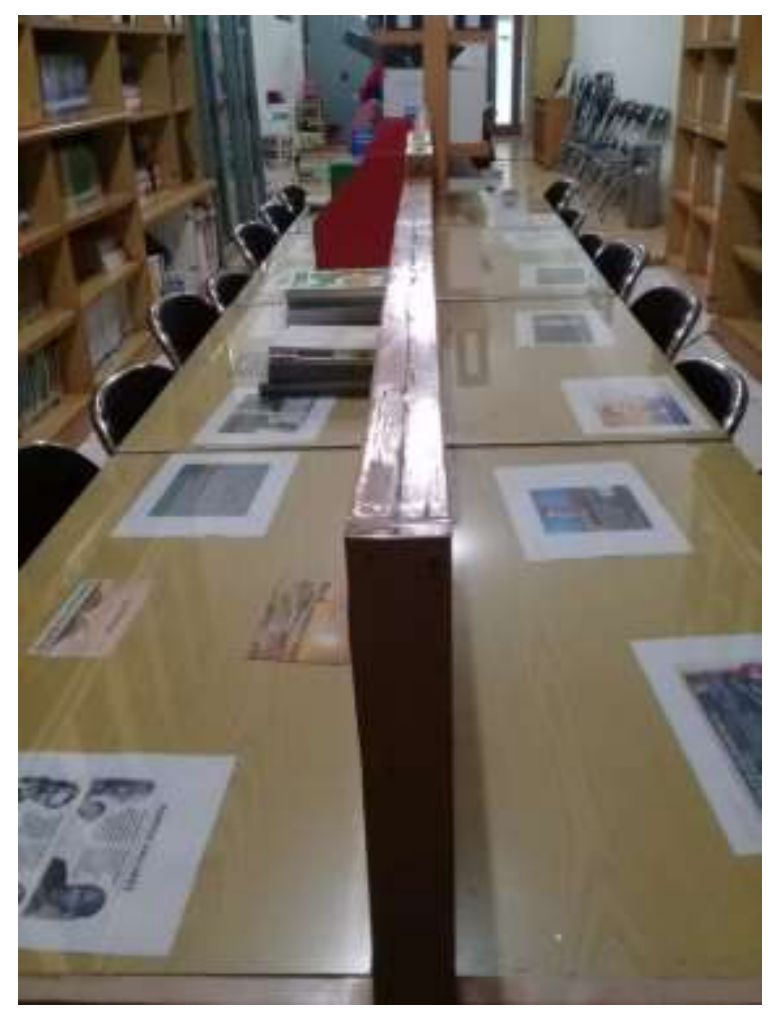




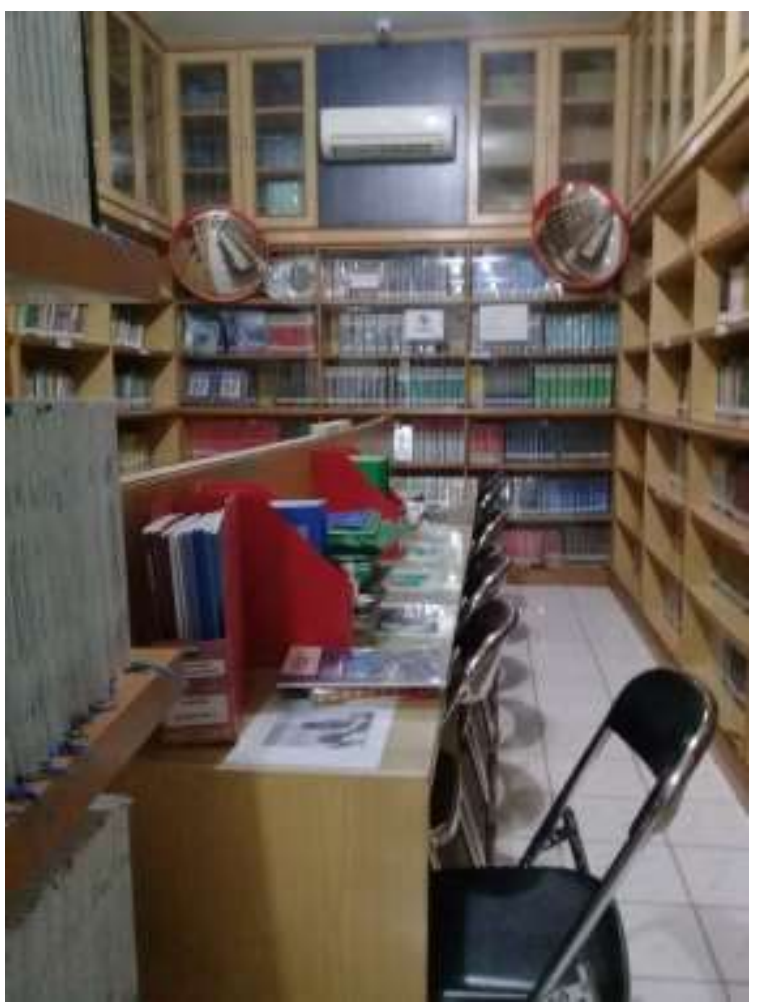

Gambar 6: Layout Meja dan Kursi

Tata letak meja dan kursi tidak memberikan kenyamaan, karena letak meja dan kursi berada ditengah dan diapit oleh rak buku sebelah kanan dan kiri. Ketika pengunjung duduk maka jarak kursi dan rak buku sekitar $50 \mathrm{~cm}$, sehingga tidak memberikan banyak ruang kebebasan bagi pengunjung yang mencari buku yang berada di belakang kursi. Sedangkan ruang bagian tengah perpustakaan terlihat lebih luas, karena tidak terdapat satu pun barang. Sebaiknya tata letak kursi dan meja perpustakaan perlu di tata kembali agar memberikan kenyamaan bagi pengunjung yang sedang duduk dan mencari buku.

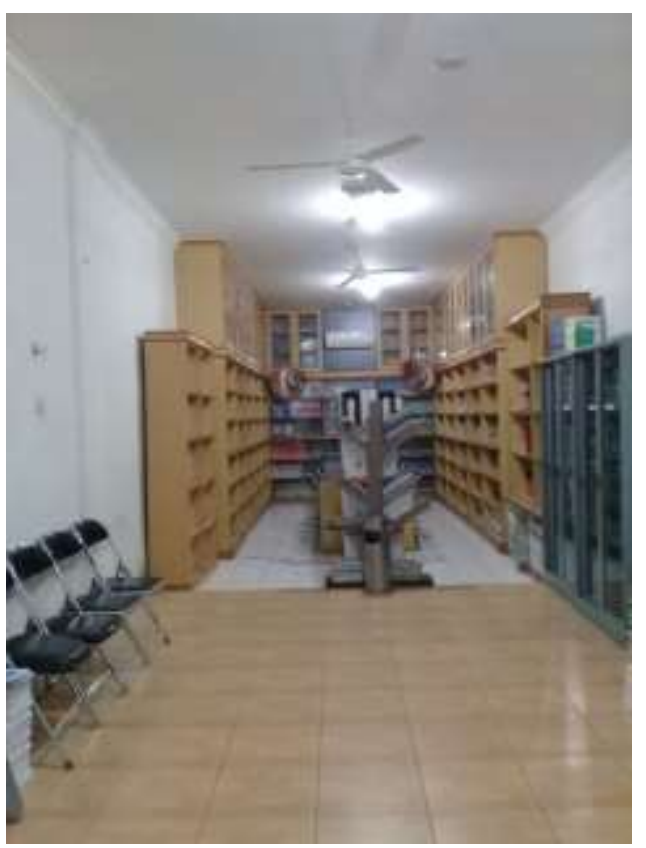

Gambar 7: Ruang Tengah Perpustakaan 


\section{Pewarnaan}

Warna bukan hal yang vital bagi perpustakaan, namun beberapa warna membuat sebuah ruangan menjadi sangat nyaman atau bahkan sangat tidak nyaman untuk dihuni warna erat kaitannya dengan kenyamanan pandangan, karena membaca memerlukan kesejukan dalam pandangan sekitarnya.Pewarnaan pada perpustakaan Universitas Potensi Utama terkait furniture berupa meja dan rak buku, dinding, lantai menggunakan warna yang tidak terlalu terang dan gelap. Warna yang digunakan dapat dikatakan sudah baik karena menggunakan warna yang soft yaitu warna cream untuk rak buku,meja, dan lantai, selain itu lantai juga menggunakan warna keramik putih. Warna-warna yang harus dihindari adalah warna yang terlalu terang atau menylaukan, sehingga dapat mengganggu kenyamanan dalam membaca dan mengakses informasi lainnya.

\section{Pencahayaan}

Cahaya adalah elemen yang perlu dipertimbangkan dalam sebuah rancangan interior Perpustakaan. Cahaya lampu merupakan cahaya tambahan untuk menerangi ruangan, hal ini dilakukan karena kondisi ruangan perpustakaan untuk memperoleh cahaya alami masuk ke dalam ruangan sangatlah minim. Ruang perpustakaan Universitas Potensi Utama terletak di lantai 2. Tujuan utama pencahayaan dalam perpustakaan adalah untuk meningkatkan fungsi perpustakaan karena pencahayaan merupakan salah satu unsur penting dalam sebuah gedung atau bangunan termasuk perpustakaan.Faktor yang menentukan berhasil tidaknya perencanaan pencahayaan di dalam ruangan tergantung dari kondisi bangunan itu sendiri. Pencahayaan buatan seperti lampu adalah suatu alat yang dapat membantu penerangan di setiap ruangan. Pencahayaan yang baik di dalam perpustakaan adalah pencahayaan yang tidak menyebabkan terjadinya penurunan gairah untuk membaca dan tidak membuat silau.

Pencahayaan di perpustakaan Universitas Potensi Utama tidak dibuat terlalu terang karena akan membuat pengunjung merasa tidak nyaman sehingga mengakibatkan kepala pusing dan mata sakit akibat pantulan dari cahaya lampu dengan buku yang sedang dibaca. Pencahayaan yang redup juga tidak bagus karena dapat merusak mata, maka dari itu diperlukan penataan cahaya yang sesuai dengan kebutuhan pada ruang perpustakaan.

\section{Suhu Udara}

Suhu udara sangat penting untuk menimbulkan kenyamanan pada runga tertutup. Suhu ruangan pada perpustakaan harus selalu dikondisikan agar kondisinya stabil. Suhu yang harus diperhatikan tidak terlalu panas dan tidak terlalu dingin agar tidak menghilangkan rasa nyaman berada pada rung perpustakaan. Sebuah ruangan akan terasa nyaman jika udara di dalam ruangan tersebut menganduk oksigen $(\mathrm{O} 2)$ yang cukup. Pada umumnya suhu normal untuk manusia berkisar kurang lebih 24 derajat celcius, suhu udara yang tidak terlalu dingin dan tidak terlalu panas. Dengan adanya kesesuaikan temperature suhu udara yang stabil maka akan memberikan dampak positif bgai pengunjung yang berada di dalam perpustakaan. Untuk menjaga kenyamanan sebuah ruangan perlu pemasangan sebuah alat pengatur suhu yaitu AC. Perpustakaan Universitas Potensi Utama telah memasang 2 AC di dalam ruang perpustakaan, agar sirkulasi udara tetap berganti, dan tidak menimbulkan bau, sehingga pengunjung betah berlama-lama berada di dalam perpustakaan. 


\section{KESIMPULAN}

Dari pembahasan di atas dapat diambil kesimpulan bahwa pengaruh desain interior perpustakaan terhadap kenyamanan pengguna perpustakaan Universitas Potensi Utama sebaiknya diperhatikan, agar pengunjung perpustakaan merasa nyaman berada di dalam perpustakaan. Kenyamanan perpustakaan harus diperhatikan dari segi elemen-elemen desain interior. Pengaruh yang ada pada perpustakaan secara simultan dapat ditimbulkan oleh desain interior yang meliputi ruang, variasi, hirarki, area personal, pencahayaan, tata suara, suhu udara,perawatan, kualitas udara, gaya dan fashion terhadap kenyamanan pengguna. Dari hasil penelitian dapat dikatakan bahwa kenyamanan perpustakaan cukup baik, karena pewarnaan, suhu udara, pencahayaan yang telah diterapkan sudah memadai, namun untuk tata letak meja dan kursi tidak memberikan kenyamaan bagi pengunjung.

\section{DAFTAR PUSTAKA}

[1] Daryanto. 1986. "Pengetahuan Praktis Bagi Pustakawan". Dalam http://digilib.uinsuka.ac.id/8124/1/BAB\%20I\%2C\%20V\%2C\%20DAFT AR\%20PUSTAKA.pdf Diakses pada tanggal 7 Agustus.

[2] Suwarno, Wiji. 2009. "Psikologi Perpustakaan”. Jakarta: Sagung Seto.

[3] Lasa H.S. 2005. “Manajemen Perpustakaan”. Yogyakarta: Gama Media.

[4] Nurhayati Hs. Arifin, 2004. "Penataan Taman Di rumah Tinggal”.Jakarta: Gramedia.

[5] Cohen, Andrew D. 1994. "Assesing Languange Ability in the Classroom. Second Edition”.Boston: Heinle \& Heinle Publishers.

[6] Suptandar, J. Pamudji. 1995 "Manusia Dan Ruang dalam Proyeksi Desain Interior". Jakarta: UPT Penerbitan Universitas Tarumanegara.

[7] Cecilia Kugler. 2007. “10 Interior Design Consideration and Developing Brief”. 